\title{
Therapeutic Manipulation of the Enteric Microflora in Inflammatory Bowel Diseases: Antibiotics, Probiotics, and Prebiotics
}

\author{
R. BALFOUR SARTOR \\ Division of Gastroenterology and Hepatology, Department of Medicine, Microbiology and Immunology, Center for Gastrointestinal Biology \\ and Disease, University of North Carolina, Chapel Hill, North Carolina
}

Crohn's disease, ulcerative colitis, and pouchitis are caused by overly aggressive immune responses to a subset of commensal (nonpathogenic) enteric bacteria in genetically predisposed individuals. Clinical and experimental studies suggest that the relative balance of aggressive and protective bacterial species is altered in these disorders. Antibiotics can selectively decrease tissue invasion and eliminate aggressive bacterial species or globally decrease luminal and mucosal bacterial concentrations, depending on their spectrum of activity. Alternatively, administration of beneficial bacterial species (probiotics), poorly absorbed dietary oligosaccharides (prebiotics), or combined probiotics and prebiotics (synbiotics) can restore a predominance of beneficial Lactobacillus and Bifidobacterium species. Current clinical trials do not fulfill evidence-based criteria for using these agents in inflammatory bowel diseases (IBD), but multiple nonrigorous studies and widespread clinical experience suggest that metronidazole and/or ciprofloxacin can treat Crohn's colitis and ileocolitis (but not isolated ileal disease), perianal fistulae and pouchitis, whereas selected probiotic preparations prevent relapse of quiescent ulcerative colitis and relapsing pouchitis. These physiologic approaches offer considerable promise for treating IBD, but must be supported by rigorous controlled therapeutic trials that consider clinical disease before their widespread clinical acceptance. These agents likely will become an integral component of treating IBD in combination with traditional anti-inflammatory and immunosuppressive agents.

he chronic idiopathic inflammatory bowel diseases
(IBD) Crohn's disease and ulcerative colitis appear to be caused by an overly aggressive cell-mediated immune response to luminal commensal bacteria in genetically susceptible individuals. ${ }^{1,2}$ Therefore, it is rational to consider therapeutic approaches that eliminate the bacterial antigens and adjuvants that constantly drive the pathogenic immune response as a potentially important component of treating IBD, in concert with anti-inflammatory and immunosuppressant agents. Although use of narrow- and broad-spectrum antibiotics, probiotics (beneficial bacteria), prebiotics (dietary components that foster the growth of beneficial bacteria), or the combination of each of these approaches has considerable logic, unfortunately, there is quite limited documentation of efficacy of these agents in properly designed controlled trials. This clinically oriented review discusses the rationale, available evidence for the use of antibiotics, probiotics, and prebiotics, and their mechanisms of action in the treatment and prevention of Crohn's disease, ulcerative colitis, and pouchitis, and attempts to provide an objective assessment for the current and potential therapeutic role of those approaches. The reader is referred to several comprehensive reviews for additional viewpoints on this controversial topic and more extensive documentation of the literature. ${ }^{3-7}$

\section{Rationale for Treatment}

There is considerable indirect evidence that components of the complex microecology of the distal ileum and colon contribute to the pathogenesis of Crohn's disease, ulcerative colitis, and pouchitis (Table 1). ${ }^{1,8-10}$ Luminal bacterial concentrations reach $10^{7}$ to $10^{8}$ organisms/g luminal contents in the terminal ileum, $10^{11} / \mathrm{g}$ in the colon, and $10^{10-11}$ in ileal pouches. ${ }^{11}$ These areas of highest anaerobic bacterial populations are involved preferentially in clinical IBD. Moreover, Crohn's disease reproducibly responds to diversion of the fecal stream and recurs after restoration of bowel continuity or infusion of luminal contents into the bypassed ileum ${ }^{12,13}$ and pouchitis does not occur before ileostomy takedown. These observations suggest that luminal contents provide the stimulus for intestinal inflammation. Increased concentrations of Enterobacteriaceae and Bacteroides species adhere to the mucosa of patients with Crohn's disease and

Abbreviation used in this paper: IL, interleukin.

(C) $\mathbf{2 0 0 4}$ by the American Gastroenterological Association 0016-5085/04/\$30.00 doi:10.1053/j.gastro.2004.03.024 
Table 1. Clinical Evidence for Bacteria in the Pathogenesis of IBD

\begin{tabular}{llll}
\hline \multicolumn{1}{c}{ Evidence } & \multicolumn{1}{c}{ Crohn's disease } & Ulcerative colitis & Pouchitis \\
\hline Disease in area of $\uparrow$ bacterial concentration & Terminal ileum, colon & Colon & Ileal pouch \\
$\uparrow$ mucosal adherence & Yes & Yes & $?$ \\
$\uparrow$ mucosal invasion & Yes & Yes & No \\
$\downarrow$ inflammation with bypass, bowel rest & Yes & No & Yes \\
Response to antibiotics & Colon only & Yes \\
Protection by probiotics & $?$ & Yes & Yes \\
Pathogenetic immune response to bacteria & Yes & Yes & $?$ \\
Exacerbation by pathogens & Yes & Yes \\
\hline
\end{tabular}

$\uparrow$, increased; $\downarrow$, decreased; ?, not studied.

ulcerative colitis ${ }^{14}$ and invade the mucosa, especially adjacent to ulcers and fistulae. ${ }^{15}$ Genetic susceptibility in a subset of Crohn's disease patients is determined by polymorphisms in NOD 2/CARD 15, which is a cytoplasmic receptor for muramyl dipeptide, a specific component of peptidoglycan in bacterial cell walls. ${ }^{16-18}$ These NOD 2/CARD 15 polymorphisms lead to defective nuclear factor $\kappa \mathrm{B}$ activation and appear to result in inefficient epithelial (and possibly macrophage) clearance of invasive bacteria ${ }^{19}$ and perhaps defective defensin production and secretion. ${ }^{20}$ Furthermore, IBD patients exhibit loss of immunologic tolerance to commensal bacteria, with both increased T-cell and humoral immune responses. ${ }^{21,22}$ Finally, IBD patients have altered composition of commensal enteric bacteria with increased $B a c$ teroides, adherent/invasive Escherichia coli, Enterococci, and decreased Bifidobacterium and Lactobacillus species (Table 2). ${ }^{23}$ Conclusive evidence for a primary role for nonpathogenic enteric bacteria is provided by the lack of enterocolitis in genetically engineered germ-free (sterile) mice, rats, and guinea pigs that reproducibly develop intestinal inflammation and T helper-1(TH1) or T helper 2(TH2) immune responses to cecal bacterial antigens within 1-4 weeks after colonization with commensal gut bacteria. ${ }^{1}$ Host susceptibility, mediated by genes regulating mucosal immune responses, barrier function, and

Table 2. Balance of Protective Vs. Aggressive Enteric Commensal Microbial Species

\begin{tabular}{ll}
\hline Beneficial & Aggressive/detrimental \\
\hline $\begin{array}{c}\text { Lactobacillus } \\
\text { species } \\
\text { Bifidobacterium } \\
\text { species }\end{array}$ & Selected B. species \\
$\begin{array}{c}\text { Selected } \text { E. coli } \\
\text { strains }\end{array}$ & Adherent/invasive, toxigenic E. coli strains \\
$\begin{array}{c}\text { Streptobacillus } \\
\text { salivarius }\end{array}$ & Eubacterium and Peptostreptococcus species \\
$\begin{array}{c}\text { Saccharomyces } \\
\text { boulardii }\end{array}$ & Fusobacterium varium \\
$\begin{array}{c}\text { Clostridium } \\
\text { butyricum }\end{array}$ & Intestinal Helicobacter species \\
\hline
\end{tabular}

microbial defenses, determine response to commensal bacteria. Wild-type mice and rats exist in harmony with the same bacteria. ${ }^{24,25}$ Importantly, commensal enteric bacterial species have selective abilities to induce immune-mediated colitis: some are pathogenic, some neutral, and some protective; these selective responses appear to be host and even regional specific in various mouse models. ${ }^{24-26}$ These results suggest that luminal commensal bacteria provide the antigenic stimulation for pathogenic immune responses in IBD, that genetic predisposition is critical to developing dysregulated immune responses to bacteria, and that the relative balance of beneficial vs. aggressive commensal enteric microflora determines mucosal homeostasis vs. inflammation (Table 2). This latter concept provides the rationale for selective therapeutic manipulation of the enteric bacterial population by antibiotics, probiotics, and prebiotics.

\section{Antibiotics}

Antibiotics are widely recognized to have an essential role in treating the septic complications of IBD, including the intra-abdominal and perianal abscesses and fistulae of Crohn's disease, as well as superinfection with pathogens and postoperative wound infection (Table 3). Most clinicians also use broad-spectrum antibiotics as adjuvant treatment of fulminant colitis and toxic megacolon to decrease bacterial translocation. Small bowel bacterial overgrowth is more common than usually per-

Table 3. Complications of IBD Requiring Antibiotic Treatment (With or Without Definitive Therapy)

Intra-abdominal, hepatic, or perianal abscesses, inflammatory phlegmon

Fistulae (perianal, enteroenteric, enterocolonic, enterocutaneous, and enterovesicle)

Anal fissures

Small intestinal bacterial overgrowth secondary to strictures, loss of ileocecal valve, enteroenteric and enterocolonic fistulae

Postoperative infections

Toxic megacolon

Secondary infections (C. difficile, and so forth) 
Table 4. Mechanisms of Action for Antibiotics in IBD

Decrease luminal and adherent mucosal bacterial concentrations

Selectively eliminate detrimental luminal bacterial subsets (alter ratio of beneficial to aggressive commensal bacteria)

Decrease tissue invasion, treat microabscesses and secondary bacterial proliferation adjacent to mucosal ulcers and fistulae

Decrease bacterial translocation and systemic dissemination of viable bacteria

ceived, ${ }^{27,28}$ particularly with loss of the ileocecal valve, clinically significant stricturing with partial small bowel obstruction and delayed transit, and enterocolonic fistulae. The use of antibiotics in these clinical settings is empiric, although uncontrolled trials do show efficacy of high-dose $(20 \mathrm{mg} / \mathrm{kg})$ metronidazole (see later). ${ }^{29}$

Antibiotics as primary or adjuvant treatment of active luminal Crohn's disease and ulcerative colitis are more controversial. Although the therapeutic rationale for using antibiotics active against enteric commensal bacteria is strong, based on the convincing data incriminating endogenous luminal bacterial adjuvants and antigens in the pathogenesis of experimental enterocolitis and IBD, and the mechanisms of protection are rational (Table 4), controlled clinical trials supporting use of these agents in IBD patients is meager at best. ${ }^{1,3,30,31}$ This review briefly summarizes representative published studies (Table 5) and attempts to derive broad conclusions based on available data. Readers are referred to a more extensive recent review of this topic for details of individual trials. ${ }^{3}$

\section{Crohn's Disease}

Broad-spectrum antibiotics are used to treat Crohn's disease by experienced investigators, ${ }^{32}$ but largescale rigorously controlled trials have never been performed. $3,30,33$ In contrast to these uncontrolled observations, use of metronidazole ( 10 or $20 \mathrm{mg} / \mathrm{kg} /$ day) is reasonably well documented to be beneficial for primary or adjunctive therapy of colonic Crohn's disease, but not for isolated small intestinal involvement. However, results for unselected patients are less conclusive. In a randomized placebo-controlled trial, Sutherland et al. ${ }^{34}$ reported that treatment with metronidazole for 16 weeks significantly decreased the Crohn's disease activity index (CDAI) from entry levels in unselected patients but had no difference in the rates of remission and only $53 \%$ of patients completed the trial. Benefit was dose dependent, with $20 \mathrm{mg} / \mathrm{kg}$ having greater efficacy than $10 \mathrm{mg} / \mathrm{kg}$. In a multicenter Scandinavian trial, therapeutic response to metronidazole $(800 \mathrm{mg} /$ day or approximately $10 \mathrm{mg} / \mathrm{kg}$ )

Table 5. Representative Antibiotic Trials in IBD

\begin{tabular}{|c|c|c|c|c|}
\hline Author & Date & Antibiotic & Duration of treatment & Result \\
\hline \multicolumn{5}{|c|}{ Crohn's disease_-primary therapy } \\
\hline Ursing 35 & 1982 & Metronidazole $800 \mathrm{mg} / \mathrm{d}$ & $16 \mathrm{wk}$ & No difference from sulfasalazine \\
\hline Sutherland ${ }^{34}$ & 1991 & Metronidazole 10 or 20 mg/kg & $16 \mathrm{wk}$ & $\begin{array}{l}\text { Superior to placebo ( } \downarrow \text { CDAI), no } \\
\text { difference in remission }\end{array}$ \\
\hline Colombel $^{41}$ & 1999 & Ciprofloxacin $500 \mathrm{mg} 2 \times$ day & 6 wk & No difference from mesalamine \\
\hline Arnold $^{42}$ & 2002 & Ciprofloxacin 500 mg $2 \times$ day & $6 \mathrm{mo}$ & Superior to placebo ( $\downarrow$ CDAI) \\
\hline Prantera 43 & 1996 & $\begin{array}{l}\text { Ciprofloxacin } 500 \mathrm{mg} 2 \times \text { day }+ \\
\text { metronidazole } 250 \mathrm{mg} 4 \times \text { day }\end{array}$ & $12 \mathrm{wk}$ & No difference from prednisolone \\
\hline Greenbloom 36 & 1998 & $\begin{array}{l}\text { Ciprofloxacin } 500 \mathrm{mg} 2 \times \text { day }+ \\
\text { metronidazole } 250 \mathrm{mg} 3 \times \text { day }\end{array}$ & $10 w k$ & Uncontrolled, $68 \%$ remission \\
\hline Leiper 45 & 2000 & Clarithromycin 250 mg $2 \times$ day & 4 wk & $\begin{array}{l}\text { Uncontrolled, } 64 \% \text { response, } 48 \% \\
\text { remission }\end{array}$ \\
\hline Steinhardt 37 & 2002 & $\begin{array}{l}\text { Ciprofloxacin } 500 \mathrm{mg} 2 \times \text { day }+ \\
\text { metronidazole } 250 \mathrm{mg} 3 \times \text { day }\end{array}$ & $8 w k$ & $\begin{array}{l}\text { No improvement over budesonide alone } \\
\text { (33\% vs. } 38 \% \text { remission) }\end{array}$ \\
\hline \multicolumn{5}{|c|}{ Crohn's disease_-prevention of postsurgical relapse } \\
\hline Rutgeerts ${ }^{38}$ & 1995 & Metronidazole $20 \mathrm{mg} / \mathrm{kg}$ & $12 \mathrm{wk}$ & $\downarrow$ clinical relapse 1 yr vs. placebo \\
\hline Rutgeerts 39 & 1999 & Ornidazole $1 \mathrm{~g} / \mathrm{d}$ & $52 \mathrm{wk}$ & $\begin{array}{l}\downarrow \text { severe endoscopic relapse vs. } \\
\text { placebo }\end{array}$ \\
\hline \multicolumn{5}{|c|}{ Ulcerative colitis_primary therapy } \\
\hline Turunen $^{58}$ & 1999 & Cipro 500 mg $2 \times$ day & $6 \mathrm{mo}$ & Superior to placebo \\
\hline Mantzaris 59 & 1997 & Cipro 500 mg $2 \times$ day & & No benefit vs. placebo \\
\hline \multirow[t]{2}{*}{ Casellas ${ }^{134}$} & 1998 & Amoxicillin $1 \mathrm{~g} /$ & & \\
\hline & & Clavaline acid $250 \mathrm{mg}$ & 5 days & $\begin{array}{l}\downarrow \text { mucosal IL-8 and eicosanoids vs. } \\
\text { placebo }\end{array}$ \\
\hline \multicolumn{5}{|l|}{ Pouchitis } \\
\hline Madden64 & 1994 & Metronidazole $400 \mathrm{mg} 3 \times$ day & 4 wk & Superior to placebo \\
\hline Shen 66 & 2001 & $\begin{array}{l}\text { Metronidazole } 20 \mathrm{mg} / \mathrm{kg} \text { or } \\
\text { Cipro } 500 \mathrm{mg} 2 \times \text { day }\end{array}$ & $2 w k$ & Both effective, Cipro $>$ metronidazole \\
\hline Gionchetti67 & 1999 & $\begin{array}{l}\text { Cipro } 500 \mathrm{mg} 2 \times \text { day and } \\
\text { Rifaximin } 1 \mathrm{~g} 2 \times \text { day }\end{array}$ & 15 days & $\begin{array}{l}89 \% \text { response, } 33 \% \text { remission, } \\
\text { uncontrolled }\end{array}$ \\
\hline
\end{tabular}


was similar to that of sulfasalazine ${ }^{35}$ as primary treatment of Crohn's disease. In both studies, metronidazole was effective for colonic and ileocolonic Crohn's disease, but not for isolated ileitis. ${ }^{34,35}$ Similarly, the combination of ciprofloxacin and metronidazole is more effective for Crohn's disease affecting the colon than for isolated small intestinal disease. ${ }^{36,37}$ Rutgeerts et al. ${ }^{38}$ reported that high-dose metronidazole $(20 \mathrm{mg} / \mathrm{kg} /$ day $)$ begun immediately after resection and continued for 3 months significantly decreased the incidence of deep mucosal ulceration in the neoterminal ileum 6 months after surgery and the clinical recurrence rates at 1 year, with a trend toward protection over the 3 years of observation. Although this provocative report suggests a role for anaerobic luminal bacteria in the postoperative recurrence of Crohn's disease, toxic doses $(20 \mathrm{mg} / \mathrm{kg} / \mathrm{day})$ of metronidazole were used and treatment was continued only for 3 months after surgery. Similarly, the related antibiotic ornidazole used continuously for 1 year significantly decreased severe recurrent ulcers in the neoterminal ileum at 3 and 12 months. ${ }^{39}$ Although most antibiotics only transiently alter luminal bacterial concentrations owing to proliferation of resistant strains, chronic use of metronidazole eliminated Bacteroides species in Crohn's disease patients for at least 6 months. ${ }^{40}$ Moreover, the clearance of fecal Bacteroides species correlated with disease remission. Metronidazole has significant side effects that include nausea, anorexia, dysgeusia, dyspepsia, and peripheral neuropathy that limit use of this agent in approximately $20 \%$ of patients.

Other single and combination antibiotic regimens can treat Crohn's disease effectively. Ciprofloxacin is comparable with mesalamine $4 \mathrm{~g} / \mathrm{day}^{41}$ and superior to placebo $^{42}$ in treating active Crohn's disease. The primary outcome of the latter study of patients with moderately active, resistant Crohn's disease was a decrease in CDAI rather than the more standard induction of remission. However, the mean CDAI level at the end of ciprofloxacin treatment was 112 , well below the remission cut-off level of 150, in contrast to a mean CDAI of 205 in the placebo group. The combination of ciprofloxacin and metronidazole can be effective in Crohn's colitis, ${ }^{36,43}$ although a retrospective analysis did not show benefit of the combination over either agent alone, with each approximately $70 \%$ effective. ${ }^{44}$ Prantera et al. ${ }^{43}$ reported no difference in the outcome of Crohn's disease patients treated with ciprofloxacin plus metronidazole ( $46 \%$ remission rate) vs. methylprednisolone (63\% remission) for 12 weeks. However, more antibiotic-treated $(27 \%)$ than steroid-treated $(11 \%)$ patients failed therapy. A similar remission rate was obtained in a 10-week open-label study of combined ciprofloxacin and metronidazole; best results were seen in patients concomitantly treated with corticosteroids and without previous surgery. ${ }^{36}$ Based on these results, Steinhart et al. ${ }^{37}$ examined the ability of metronidazole plus ciprofloxacin to improve the effects of ileal-release budesonide in patients with ileal or ileoright colonic Crohn's disease. The overall response rates were no different (38\% budesonide + placebo vs. $33 \%$ budesonide + antibiotics), with increased toxicity in the antibiotic group (20\% vs. $0 \%$ withdrawal rates), but analysis by disease site showed better antibiotic responses in the small number of patients $(\mathrm{N}=33)$ with colonic involvement (53\% remission with antibiotics vs. $25 \%$ remission with placebo, $P>0.10$ ). Multiple studies with clarithromycin as part of an antimycobacterial regimen showed some benefit (see later), but interpretation was difficult because of the multiple drugs involved. Uncontrolled use of clarithromycin alone induced $64 \%$ response and $48 \%$ remission rates in resistant Crohn's disease patients treated for 4 weeks. ${ }^{45} \mathrm{~A}$ pilot study suggested that rifaximin may have a role in treating Crohn's disease based on 78\% response and 59\% remission rates after 4 months of treatment. ${ }^{46}$

Several different combinations of antimycobacterial agents have been used in Crohn's disease patients to explore the hypothesis that mycobacterial species cause this disorder. The majority of trials using conventional triple or quadruple antimycobacterial treatments have been negative, ${ }^{47}$ but $M$. paratuberculosis is resistant to these traditional agents. Combinations of rifabutin and a macrolide, usually clarithromycin, with or without clofazamine, appear more promising. ${ }^{48-50}$ These small uncontrolled studies report responses ranging from $58 \%$ to $83 \%$, with some patients showing mucosal healing and sustained remissions off anti-inflammatory medications. However, up to $20 \%$ of patients withdrew from these trials owing to drug side effects. These studies have been inconclusive regarding the role of $M$. paratuberculous owing to the broad spectra of activity of these antibiotics, failure to document selective responses in those patients with evidence of $M$. paratuberculosis infection by either polymerase chain reaction or serology, and lack of documentation of clearance of tissue infection in patients who respond to treatment. Ongoing, large, controlled trials in Australia and the United States will help settle these issues.

The same antibiotics used to treat luminal Crohn's disease have been reported to be beneficial in the treatment of perianal Crohn's disease. ${ }^{3,51}$ Unfortunately, no controlled studies have been performed and fistulae tend to recur in many patients after cessation of treatment. 
The largest studies reported $62 \%$ to $83 \%$ closure rates to metronidazole $20 \mathrm{mg} / \mathrm{kg}^{29,52}$ The combination of metronidazole and ciprofloxacin improved perianal fistulae in 9 of 14 patients (64\% response rate) and closure in 3 of $14(21 \%)$ patients. ${ }^{53}$ Although these uncontrolled results are not definitive, many clinicians, including this author, use metronidazole, ciprofloxacin, the combination of these agents, or tetracycline as the first-line treatment of perianal Crohn's disease in conjunction with surgical drainage of associated abscesses. 6 Mercaptopurine/azathioprine, infliximab, or tacrolimus can be reserved for patients not responding to antibiotics. Clinicians must warn patients about the likelihood of peripheral neuropathy with high-dose metronidazole therapy. Paresthesias are dose and time dependent, with relatively low frequency at $10 \mathrm{mg} / \mathrm{kg} / \mathrm{day}$, but an incidence of up to $50 \%$ with higher doses. ${ }^{54}$ Paresthesias usually are reversible if metronidazole is stopped when first detected but can be irreversible if treatment is continued despite symptoms.

\section{Ulcerative Colitis}

Although antibiotics cannot be advocated for treating ulcerative colitis based on available trials, several preliminary studies suggest their possible benefit as adjuncts to standard anti-inflammatory therapy. Brief tobramycin therapy had long-term benefits ${ }^{55,56}$ and $90 \%$ of patients treated for 18 months with trimethoprim/sulfamethoxazole improved. ${ }^{57}$ Turunen et al. ${ }^{58}$ showed a modest additive effect for ciprofloxacin in the long-term management $(6 \mathrm{mo})$ of ulcerative colitis, particularly in steroid-treated patients, although short courses of intravenous or oral ciprofloxacin were not effective. ${ }^{59,60}$ However, the nonabsorbable broad-spectrum antibiotic rifaximin may have some promise, ${ }^{61}$ consistent with the observation that the addition of multiple broad-spectrum antibiotics occasionally produce dramatic benefits in patients with fulminant refractory ulcerative colitis, despite the absence of demonstrable pathogens. ${ }^{62} \mathrm{~A}$ small trial in ulcerative colitis patients showed that 3 intermittent courses of rifaximin did not permanently alter the colonic microbiota, although resistant Bifidobacterium species were found. ${ }^{63}$

\section{Pouchitis}

Overgrowth of commensal bacteria have been postulated to cause pouchitis in patients with ileal pouchanal anastomoses, based on the predictable response to short-term treatment with metronidazole and other antibiotics in most patients. ${ }^{64,65}$ In a controlled trial with a cross-over design, $73 \%$ of patients with active pouchitis responded to metronidazole vs. a $10 \%$ response to placebo. ${ }^{64}$ Both high-dose metronidazole $(20 \mathrm{mg} / \mathrm{kg})$ and ciprofloxacin $(1000 \mathrm{mg} /$ day $)$ treatment for 2 weeks significantly decreased objective pouch inflammation, with better results and less toxicity seen in the ciprofloxacintreated group. ${ }^{66}$ The combination of ciprofloxacin plus rifaximin is effective in the majority $(89 \%)$ of patients with refractory pouchitis. ${ }^{67}$

\section{Lessons From Animal Models}

In several rodent models metronidazole or ciprofloxacin can prevent onset of experimental colitis, but not reverse established disease, whereas broad-spectrum antibiotics both prevent and treat active inflammation. ${ }^{68-72}$ Of interest, metronidazole and ciprofloxacin had selective protective effects in different colonic regions, ${ }^{70}$ suggesting that different bacterial species cause disease in various colonic segments. Broad-spectrum antibiotics are effective in almost all models of acute and chronic colitis and ileitis in mice, rats, and guinea pigs. ${ }^{72-75}$ However, in human leukocyte antigen (HLA)-B27 transgenic rats even broad-spectrum antibiotics have only transient benefit, with recurrence of colitis 1 month after cessation of treatment; probiotics could prevent this relapse of disease. ${ }^{76}$ These results indicate that commensal enteric bacteria have synergistic activities in the induction and perpetuation of intestinal inflammation. Therapeutic implications of these studies are that most forms of clinical IBD should respond to treatment if the proper combination of broad-spectrum antibiotics are used, antibiotics should be individualized for the region involved (ileum, cecum, distal colon), and that sequential treatments with antibiotics followed by probiotics should be examined, as has been quite effective in chronic pouchitis. ${ }^{77}$

\section{Conclusions}

These diverse studies strongly implicate enteric commensal bacteria in the pathogenesis of Crohn's disease and pouchitis, and suggest that both aerobic and anaerobic bacteria contribute to the inflammatory response. There is presumptive evidence that metronidazole, ciprofloxacin, or the combination of these antibiotics are effective in Crohn's colitis and ileocolitis, but not in isolated ileal disease. The author uses antibiotics in Crohn's colitis, ileocolitis, and perianal fistulae in conjunction with 5-aminosalicylic acid (5-ASA), corticosteroids, and, in appropriate settings, immunosuppressive agents rather than as single agents. However, use of antibiotics as primary therapy of Crohn's disease is poorly documented, owing to significant defects in the study design, high dropout rates, and inadequate numbers of study subjects in the available studies. Equivalency studies are underpowered for definitive results and comparisons frequently are made against sulfasalazine or me- 
Table 6. Randomized Double-Blind Trials of Probiotic Agents in IBD

\begin{tabular}{|c|c|c|c|}
\hline Author (date) & Probiotic & Clinical situation & Result \\
\hline \multicolumn{4}{|l|}{ Crohn's disease } \\
\hline Plein, Hotz (1993)135 & Saccharomyces boulardii & Maintenance of remission & $\downarrow$ diarrhea vs. placebo \\
\hline Malchow $(1997)^{93}$ & E. coli Nissle 1917 & Maintenance of remission & $\downarrow$ relapse vs. placebo \\
\hline Guslandi (2000) ${ }^{136}$ & S. boulardii & $\begin{array}{l}\text { Maintenance of remission (probiotic }+ \\
\text { mesalamine vs. mesalamine alone) }\end{array}$ & $\begin{array}{l}\downarrow \text { relapse vs. mesalamine } \\
\text { alone }\end{array}$ \\
\hline Prantera $(2002)^{94}$ & Lactobacillus GG & Postoperative prevention & No benefit \\
\hline \multicolumn{4}{|l|}{ Ulcerative colitis } \\
\hline Kruis $(1997)^{85}$ & E. coli Nissle 1917 & Maintain remission & Equal to mesalamine (1.6 g) \\
\hline Rembacken (1999) ${ }^{86}$ & E. coli Nissle 1917 & Maintain remission & Equal to mesalamine \\
\hline Kruis $(2001)^{87}$ & E. coli Nissle 1917 & Maintain remission & Equal to mesalamine \\
\hline Ishikawa (2003) ${ }^{88}$ & Bifidobacteria-fermented milk & Maintain remission & Superior to placebo \\
\hline \multicolumn{4}{|l|}{ Pouchitis } \\
\hline Gionchetti $(2000)^{77}$ & VSL\#3 & Maintain remission chronic pouchitis & Superior to placebo \\
\hline Mimura $(2002)^{83}$ & VSL\#3 & Maintain remission chronic pouchitis & Superior to placebo \\
\hline Gionchetti (2003) $)^{84}$ & VSL\#3 & Prevention after ileostomy closure & Superior to placebo \\
\hline
\end{tabular}

salamine, which themselves have questionable efficacy in Crohn's disease. The use of antibiotics in ulcerative colitis currently is not justified based on available studies, although broad-spectrum regimens need to be explored. Although proper trials of antibiotics in pouchitis have not been conducted, widespread clinical efficacy of most antibiotics active against enteric bacteria validate their use.

Rigorous multicenter studies for optimal antibiotic regimens in Crohn's disease (primary therapy and prevention of relapse) need to be conducted using broadspectrum agents or combinations of narrow-spectrum agents. It will be important to carefully consider responses in subsets of disease using genetic, clinical, or serologic markers. When used in Crohn's disease of the colon, treatment should be for 2-3 months duration and the patient must be alerted to the risk for peripheral neuropathy with sustained use of high doses of metronidazole.

\section{Probiotics}

Probiotics are viable microorganisms with beneficial physiologic or therapeutic activities. Originally derived from cultured foods, especially milk products, these protective bacteria and yeast include the lactic acid bacilli, Lactobacillus and Bifidobacterium, a nonpathogenic E. coli strain (E. coli Nissle 1917), Saccharomyces boulardii, Clostridium butyricum, and Streptococcus salivarius subspecies thermophiles. More recently, genetically engineered bacteria that secrete immunosuppressive substances such as interleukin-10 (IL-10) have been studied.

Limited clinical trials suggest that selected probiotic species, alone or in combination, can prevent recurrent intestinal inflammation and possibly treat active IBD, with best results in pouchitis, and, to a lesser extent, ulcerative colitis (Table 6). These results have generated considerable enthusiasm, as evidenced by more recent reviews than primary studies. ${ }^{6,78-82}$

\section{Pouchitis}

The most convincing evidence of the clinical efficacy of probiotics in clinical IBD is provided by a small, prospective, double-blind, placebo-controlled trial showing that daily administration of a combination of 4 Lactobacillus species, 3 Bifidobacterium species, and $1 \mathrm{~S}$. salivarium species (VSL 3) for 9 months prevented relapse of chronic pouchitis after induction of remission by antibiotics. ${ }^{77}$ The relapse rate of VSL 3-treated patients was $15 \%$ (3 of 20 patients) vs. $100 \%$ in the placebotreated group $(\mathrm{N}=20)$. Moreover, every patient relapsed within 3 months of stopping VSL 3. These results have been replicated ${ }^{83}$ and extended by decreasing the frequency of pouchitis by prospectively administering VSL 3 beginning at the time of pouch closure. ${ }^{84}$ In this prophylactic study, 2 of 20 patients $(10 \%)$ receiving 1 packet of VSL 3 containing 900 billion bacteria/day for 1 year developed pouchitis vs. $40 \%$ of placebo-treated patients. Moreover, median stool frequency in subjects not developing pouchitis was significantly less (5 vs. 8 stools/day) in VSL 3 vs. placebo-treated patients. ${ }^{84}$

\section{Ulcerative Colitis}

Several probiotic preparations show promise in ulcerative colitis, although results are not as convincing as in pouchitis. E. coli Nissle 1917 was reported to be as effective as low-dose 5-ASA in preventing relapse of ulcerative colitis. ${ }^{85-87}$ A small study showed that administration of Bifidobacteria-fermented milk decreased the rate of relapse of ulcerative colitis to 3 of 11 treated 
subjects vs. 9 of 10 controls. ${ }^{88}$ Uncontrolled pilot studies have indicated that VSL 3 maintained remission of ulcerative colitis in $75 \%$ of patients over 12 months $^{89}$ and reduced active inflammation in $87 \%$ of ambulatory patients with mild to moderate disease. ${ }^{90}$ Similarly, uncontrolled administration of the nonpathogenic yeast $S$. boulardii for 4 weeks induced a clinical remission in 17 of 24 (71\%) of patients with mild to moderate ulcerative colitis. ${ }^{91}$ A provocative study by Borody et al. ${ }^{92}$ addressed the hypothesis that ulcerative colitis patients have abnormal enteric bacteria. They showed reversal of refractory ulcerative colitis in 6 patients who were repopulated with fecal enemas from normal patients.

\section{Crohn's Disease}

Results of probiotic trials in Crohn's disease are mixed. Malchow ${ }^{93}$ found that E. coli Nissle was superior to placebo in preventing relapse of Crohn's disease after induction of remission by standard medical therapy, but Prantera et al. ${ }^{94}$ reported no benefit of Lactobacillus $G G$ administered for 1 year in preventing postoperative relapse of symptoms or endoscopic lesions in the neoterminal ileum. However, a pilot study of Lactobacillus $G G$ reported benefit in pediatric patients with active Crohn's disease with successful tapering of steroids in 3 of 4 patients. ${ }^{95}$

\section{Lessons From Animal Models}

Animal models are useful to study optimal treatment protocols and to evaluate mechanisms by which probiotic microbial agents mediate their protective effects. A number of Lactobacillus and Bifidobacterium species attenuate experimental colitis in IL-10 knockout mice, including native murine $L$. reuteri, ${ }^{96}$ VSL $3,{ }^{97} L$. plantarum, ${ }^{98}$ L. salivarius, and B. infantis. 99 Host background appears to be important because $L$. plantarum but not Lactobacillus GG can prevent colitis in HLA B27 transgenic rats. ${ }^{76}$ This study and many others indicate that various probiotic species have different protective effects in selected hosts and inflammatory conditions. Of note, probiotic bacteria were able to prevent recurrence of colitis in HLA B27 transgenic rats after induction of remission with broad-spectrum antibiotics, but could not by themselves induce a remission of established disease. ${ }^{76}$ These results suggest that probiotic agents may be more effective in preventing relapse of disease than in inducing remission and that sequential administration of antibiotics to induce a remission followed by probiotics to maintain quiescent disease may be an effective longterm synergistic approach to clinical management of IBD patients. This possibility is supported by clinical trials in refractory pouchitis patients. ${ }^{77}$ Finally, a novel approach
Table 7. Mechanisms of Action of Probiotics

Inhibit pathogenic enteric bacteria
Decrease luminal pH
Secrete bacteriocidal proteins
Colonization resistance (occupy ecologic niche)
Block epithelial binding-induction of MUC 2
Inhibit epithelial invasion-Rho-dependent and -independent
pathways
Improve epithelial and mucosal barrier function
Produce short chain fatty acids, including butyrate
Enhance mucus production
Increase barrier integrity
Alter immunoregulation
Induce IL-10, transforming growth factor $\beta$ expression and
secretion
Stimulate secretory immunoglobulin A production
Decrease tumor necrosis factor expression

to probiotic therapy is suggested by prevention and treatment of colitis in 2 murine models by daily administration of Lactococcus lactis, engineered to secrete recombinant IL-10. ${ }^{100}$ This approach is now in pilot trials in IBD patients.

\section{Mechanisms of Protection by Probiotics}

Multiple mechanisms of action have been suggested to explain the protective effects of probiotic agents in intestinal inflammation (Table 7). These can be classified broadly as suppression of growth or epithelial binding/invasion by pathogenic bacteria, improved epithelial barrier function, or immunoregulatory activities. A detailed description of these mechanisms is beyond the scope of this clinically oriented review, but several recent examples of each category are provided. Bifidobacterium infantis suppressed growth of Bacteroides vulgatus, ${ }^{101}$ an organism associated with IBD and experimental colitis. ${ }^{24,102}$ Similarly, Bifidobacterium-fermented milk decreased fecal $B$. vulgatus concentrations in ulcerative colitis. ${ }^{88}$ Suppression of the growth and function of enteric pathogenic bacteria has been attributed to decreased luminal $\mathrm{pH}$ via production of short chain fatty acids, secretion of bactericidal proteins, and prevention of epithelial adherence. E. coli Nissle 1917 inhibited both in vitro epithelial adhesion and invasion by an adherent/ invasive E. coli strain isolated from Crohn's disease patients. ${ }^{103}$ Parallel results using $L$. plantarum and enteroadherent $E$. coli suggested that up-regulation of MUC-2, a primary intestinal mucin glycoprotein, by this probiotic bacterial species prevented pathogenic bacterial adherence. ${ }^{104}$ In addition, $S$. thermophilus and $L$. acidophilus prevented entry of enteroinvasive $E$. coli by rhodependent and -independent mechanisms. ${ }^{105}$ These results were confirmed by Mattar et al., ${ }^{106}$ who postulated that stimulation of mucins would decrease bacterial 
translocation. Indeed, oral or rectal administration of $L$. plantarum to mice treated with trinitrobenzene sulfonic acid decreased the translocation of commensal enteric bacteria to mesenteric lymph nodes and spleens. ${ }^{107}$ Similarly, Lactobacillus $G G$ decreased E. coli translocation in rabbits. ${ }^{108}$ Although the mechanisms are not clear, mucosal permeability was decreased by administration of $L$. reuteri or VSL 3 to IL-10-/- mice. ${ }^{96,97} \mathrm{~A}$ number of studies showed that several probiotic agents can induce protective cytokines, including IL-10 and transforming growth factor $\beta$, and suppress proinflammatory cytokines, such as tumor necrosis factor, in the mucosa of patients with pouchitis and Crohn's disease, ${ }^{109-111}$ in IL-10-/- mice ${ }^{99}$ and in isolated splenocytes. ${ }^{112}$ Obviously, induction of IL-10 is not the sole mechanism of protection because multiple probiotic agents prevent and treat colitis in IL-10-deficient mice. ${ }^{96-99}$

Recent data indicate that nonviable components of probiotics can mediate their beneficial effects. Both secreted proteins and DNA of VSL 3 can block nuclear factor $\kappa \mathrm{B}$ and $\mathrm{p} 38$ mitogen-activated protein kinase activation and prevent apoptosis of epithelial cells. ${ }^{13,114}$ Interestingly, different effects are seen with DNA from different bacterial species within the VSL 3 mixture. ${ }^{113}$ Nonmethylated DNA ( $\mathrm{CpG}$ ) from VSL 3 and a randomly selected $E$. coli strain can suppress experimental colitis in several models; this suppression is mediated through TLR 9, which binds CpG. ${ }^{15}$

\section{Conclusions}

Several probiotic preparations have promise in preventing relapse of chronic pouchitis and ulcerative colitis, and possibly in the treatment of mild to moderately active ulcerative colitis and prevention of postoperative pouchitis. Results in Crohn's disease are not yet clear owing to conflicting results and a paucity of trials. This approach is quite appealing because of a lack of toxicity and to the enthusiasm of patients wishing to use natural physiologic approaches to treating IBD. Animal models suggest that optimal results may be achieved by prophylactic use of probiotics after induction of remission by antibiotics, which can suppress detrimental bacterial populations. Thus, the combinations of antibiotics and probiotics can restore the normal predominance of beneficial enteric bacteria. The optimal composition, dose, and length of probiotic treatment in various IBD clinical settings need to be determined by large, welldesigned, placebo-controlled, prospective trials. In addition, it is clear that all Lactobacillus and Bifidobacterium species are not equally beneficial, each may have individual mechanisms of action, and host characteristics may determine which probiotic species and even strain may be optimal in a given setting. Thus, one cannot consider probiotics as a generic form of therapy. Therefore, results must be interpreted accordingly and trials designed to consider phenotypic and genetic subsets of patients.

\section{Prebiotics}

Prebiotics are dietary substances, usually nondigested carbohydrates, that stimulate the growth and metabolism of protective commensal enteric bacteria. ${ }^{116,117}$ Lactosucrose, fructo-oligosaccharides, inulin, bran, psyllium, and germinated barley extracts foster the growth of Lactobacillus and Bifidobacterium species and stimulate production of short chain fatty acids, especially butyrate. ${ }^{118,119}$ Thus, these prebiotic food additives have the potential to restore the deranged balance of beneficial vs. aggressive commensal bacterial species in the distal ileum of IBD patients by several mechanisms. These physiologic substances stimulate growth of protective lactic acid bacilli, which secondarily suppress detrimental species by decreasing the luminal $\mathrm{pH}$ and by inducing colonization resistance, blocking epithelial attachment, and secretion of bactericidal substances. In addition, increased substrate availability and enhanced numbers of metabolically active Lactobacilli and Bifidobacteria increase bacterial fermentation, with resultant butyrate production that improves epithelial barrier function. The net result of prebiotic administration is functionally equivalent to administering probiotic bacteria. Although this is an extremely attractive concept for treating intestinal inflammation, experimental support for these nutriceuticals is even less extensive than that for probiotics.

\section{Human IBD}

Several small controlled studies of prebiotics have been reported in ulcerative colitis patients, but none have been performed in Crohn's disease. Germinated barley foodstuff, a glutamine- and hemicellulose-rich extract of spent beer-brewing constituents, stimulates growth of Bifidobacterium and Eubacterium species and production of butyrate and other short chain fatty acids. ${ }^{120}$ Four-week administration of 20-30 g of germinated barley extracts to patients with mild to moderate ulcerative colitis decreased clinical and endoscopic evidence of inflammation in both a pilot and a small placebo-controlled trial. ${ }^{121,122}$ This treatment increased fecal concentrations of $B i$ fidobacterium species and Eubacterium limosum. A longerterm (24 wk) open-label study of 21 patients reached similar conclusions. ${ }^{119}$ Psyllium, long used by clinicians to maintain stool consistency in both constipation and diarrhea, is a form of prebiotic by virtue of its ability to serve as a metabolic substrate for bacteria. Administra- 
tion of psyllium was superior to placebo in decreasing symptoms of patients with inactive ulcerative colitis, with a consistent increase in fecal Bifidobacterium concentrations, and decreased free water in the stool. ${ }^{123}$

\section{Lessons From Rodent Models}

A number of prebiotic preparations have been shown to inhibit experimental colitis and to increase luminal concentrations of lactic acid bacteria. Madsen et al. ${ }^{96}$ showed that lactulose enhanced growth of endogenous Lactobacilli and attenuated colitis in IL-10-deficient mice. Similarly, feeding inulin ${ }^{124}$ or germinated barley extracts ${ }^{125-127}$ inhibited dextran sodium sulfate (DSS)-induced colitis and increased luminal concentrations of short chain fatty acids, including butyrate, Lactobacilli, and Bifidobacteria. Kanauchi et al. ${ }^{127}$ reported a decrease in serum IL-6 levels and mucosal signal transducers and activators of transcription factor (STAT-2) and nuclear factor $\kappa \mathrm{B}$ activity after germinated barley foodstuff treatment of mice with DSS-induced colitis. Cherbut et al. ${ }^{128}$ reported that fructo-oligosaccharides, which promote the growth of lactic acid bacteria and increase production of butyrate and lactate, decreased trinitrobenzene sulfonic acid-induced colitis in rats. Administration of high doses $\left(10^{11}\right.$ colony forming units/ day) of intragastric lactic acid bacteria or intracolonic butyrate and lactate had similar protective effects, suggesting that the beneficial effects of prebiotics were mediated by induction of short chain fatty acids and growth of luminal probiotic bacteria. However, Moreau et al. ${ }^{129}$ reported no benefit of fructo-oligosaccharides but a protective effect of type 3 resistant starch in the DSS rat colitis model. Similarly, galacto-oligosaccharides had no protective effect in trinitrobenzene sulfonic acid-treated rats, although colonic Bifidobacteria concentrations were increased. ${ }^{130}$ Hoentjen et al. ${ }^{131}$ showed that the combination of inulin and fructo-oligosaccharides significantly decreased gross and histologic inflammation and cecal IL-1 $\beta$ concentrations while increasing cecal transforming growth factor $\beta$ secretion in HLA-B27 transgenic rats. These results suggest that the combination of several prebiotic compounds may be effective, analogous to cocktails of various probiotic bacteria. Studies in gnotobiotic rats colonized with human enteric bacteria compared dietary administration of inulin, fructo-oligosaccharide, or the combination of both prebiotic agents. ${ }^{132}$ Fructo-oligosaccharides stimulated growth of Bifidobacterium and Lactobacillus species more effectively, whereas inulin induced higher luminal concentrations of butyrate. Thus, combinations of prebiotics may have additive effects owing to multiple mechanisms of action. Similar to probiotic bacterial species, each prebiotic sub- stance has unique characteristics and therapeutic applications. Finally, nondigestible oligosaccharides suppressed in vitro growth of $C$. difficile, independent of the activities of Bifidobacterium, ${ }^{133}$ suggesting that prebiotics may be beneficial in treating bacterial toxin-induced colitis.

\section{Conclusions}

Prebiotics offer an exciting potential treatment for IBD patients, with the strong theoretic rationale of stimulating growth of endogenous protective lactic acid bacilli and production of cytoprotective butyrate. This approach promises to be safe, physiologic, and cost effective, and therefore could be considered for long-term prophylactic use and possibly applied to high-risk individuals or those with subclinical disease. However, studies of this topic are just beginning and considerable data need to be generated to provide clinical proof of efficacy in different clinical situations before these agents can be applied to widespread clinical use. Because each agent has unique properties, comparative studies of various prebiotic compounds and combinations of agents, various doses, and duration of treatment need to be performed. Certain compounds (i.e., lactulose) have important side effects, including diarrhea and gas formation, which may limit their use in IBD patients. In addition, consideration should be given to altering the patient's diet because increasing the amount of dietary fiber and natural dietary oligosaccharides while decreasing refined carbohydrates similarly may restore a healthy balance of protective vs. detrimental enteric bacterial species. Finally, the interesting approach of combining probiotic and prebiotic agents (synbiotics) has considerable appeal and may decrease the required dose, duration, or frequency of probiotic administration, thereby decreasing costs and improving compliance (adherence) to treatment.

\section{Conclusions and Future Directions}

Although the rationale for therapeutic manipulation of the luminal microbiota in IBD is uncontested, current data for therapeutic efficacy do not withstand rigorous scrutiny or fulfill current evidence-based standards for using antibiotics, probiotics, and prebiotics in the treatment of IBD. Clinical trials consistently have been underpowered to show equivalency or superiority, many have design flaws that preclude definitive results, or use outcomes, such as mean CDAI, that do not conform with widely accepted criteria for disease response or remission. Thus, enthusiasm outstrips scientific support for these therapeutic approaches. However, although cur- 
Table 8. Current and Potential Uses of Antibiotics, Probiotics, and Prebiotics in IBD Patients

\begin{tabular}{llll}
\hline & \multicolumn{1}{c}{ Reasonable evidence } & \multicolumn{1}{c}{ Suggestive evidence } & \multicolumn{1}{c}{ Potential use } \\
\hline Antibiotics & CD colitis, ileocolitis, (active), pouchitis & Postoperative prevention CD & UC (broad spectrum) \\
Probiotics & Chronic pouchitis (prevention of relapse) & Pouchitis (postoperative prevention) & UC (active) \\
& UC (prevention of relapse) & & CD (postoperative) \\
Prebiotics & None & None & CD (active) \\
\hline
\end{tabular}

$\mathrm{CD}$, Crohn's disease; UC, ulcerative colitis.

rent data do not strongly support use of these agents, most trials and clinical experience suggest therapeutic benefit of antibiotics, especially metronidazole, ciprofloxacin, the combination of these 2 agents, and, possibly, clarithromycin, in the adjunctive treatment of active Crohn's disease involving the colon and possibly in the postoperative neoterminal ileum (Table 8). Likewise, metronidazole, ciprofloxacin, and rifaximin effectively treat pouchitis. Currently approved antibiotics are not effective in active ulcerative colitis, although broad-spectrum, nonabsorbable agents show promise in early trials. Existing probiotic agents, either alone (E. coli Nissle) or in combination (VSL 3), can prevent relapse of ulcerative colitis and chronic relapsing pouchitis, respectively. The latter combination of 8 probiotic species appears promising in prevention of pouchitis with prophylactic use after ileal pouch-anal anastomosis and in the treatment of active ulcerative colitis. Prebiotics have great potential but have not been adequately tested yet in IBD to reach valid conclusions. Large, well-designed, multicenter, controlled, clinical trials need to be organized and conducted to examine the possible indications listed in Table 8 to determine whether these agents will have a place in the IBD treatment armamentarium.

Although current clinical support is weak, therapeutic manipulation of luminal microecology has considerable potential as a physiologic nontoxic approach to treating and, perhaps even more importantly, maintaining medically or surgically induced remission and ultimately preventing onset of disease in high-risk individuals. As additional susceptibility genes are defined for both Crohn's disease and ulcerative colitis, genetic testing will be used widely to screen family members and possibly the general population. Nontoxic means to treat disease at a preclinical stage or to prevent onset of inflammation in high-risk individuals will need to be developed. Probiotics and/or prebiotics may be optimal agents for prophylactic use because of their physiologic nature and lack of obvious toxicity. Similarly, these approaches may be highly amenable for life-long use to prevent recurrence in patients with IBD once a remission occurs.

Optimal application of antibiotics, probiotics, and prebiotics will depend on a clear understanding of which individual agent is indicated for a defined patient subset. Current data suggest that metronidazole and ciprofloxacin are not effective for treatment of Crohn's ileitis, but can benefit Crohn's patients with colonic involvement. It may be that different bacterial populations are responsible for disease in various intestinal regions, as suggested by selectively monoassociated IL-10-deficient mice. ${ }^{25}$ Furthermore, different bacteria may have dominant effects in different genetic backgrounds. Thus, optimal use of various antibiotics, probiotics, and prebiotics may depend on identifying patient subsets by genetic, phenotypic, stool microbiologic, serologic, or T-cell immune response criteria. Finally, antibiotics may be used optimally to eliminate certain aggressive (or pathogenic) enteric bacterial populations, followed by exogenous probiotics or prebiotics to fill the open ecologic niche, thereby permanently altering the balance of enteric microbiota for long-term efficacy. The concept of synbiotics (simultaneous use of probiotics and prebiotics) has considerable conceptual appeal and may decrease the dose, frequency, or duration of probiotic administration, thereby minimizing the expense of treatment. Similarly, concomitant use of antibiotics, probiotics, and/or prebiotics in combination with immunosuppressives to block pathogenic immune responses, growth factors to accelerate mucosal healing and to optimize mucosal barrier function, and granulocyte-macrophage colony-stimulating factor to potentiate bacterial killing and clearance provide the best hope for altering the insidious progression of idiopathic IBD.

\section{References}

1. Sartor RB. Microbial influences in inflammatory bowel disease: role in pathogenesis and clinical implications. In: Sartor RB, Sandbom WJ, eds. Kirsner's inflammatory bowel diseases. 6th ed. Edinburgh, Elsevier, 2003:138-162.

2. Podolsky DK. Inflammatory bowel disease. N Engl J Med 2002; 347:417-429.

3. Isaacs KL, Sartor RB. Antibiotics in IBD. Gastroenterol Clin North Am 2004 (in press).

4. Linskens RK, Huijsdens XW, Savelkoul PH, VandenbrouckeGrauls CM, Meuwissen SG. The bacterial flora in inflammatory bowel disease: current insights in pathogenesis and the influence of antibiotics and probiotics. Scand J Gastroenterol Suppl 2001;234:29-40.

5. Marteau P, Seksik P, Shanahan F. Manipulation of the bacterial 
flora in inflammatory bowel disease. Best Pract Res Clin Gastroenterol 2003;17:47-61.

6. Macfarlane GT, Cummings JH. Probiotics, infection and immunity. Curr Opin Infect Dis 2002;15:501-506.

7. Schultz M, Scholmerich J, Rath HC. Rationale for probiotic and antibiotic treatment strategies in inflammatory bowel diseases. Dig Dis 2003;21:105-128.

8. Biancone L, Monteleone I, Del Vecchio B, Vavassori P, Pallone F. Resident bacterial flora and immune system. Dig Liver Dis 2002;34(Suppl 2):S37-S43.

9. Cummings JH, Macfarlane GT, Macfarlane S. Intestinal bacteria and ulcerative colitis. Curr Issues Intest Microbiol 2003;4:920.

10. Guarner F, Casellas F, Borruel N, Antolin M, Videla S, Vilaseca $\mathrm{J}$, Malagelada JR. Role of microecology in chronic inflammatory bowel diseases. Eur J Clin Nutr 2002;56(Suppl 4):S34-S38.

11. Wilson $\mathrm{KH}$. Natural biota of the human gastrointestinal tract. In: Blaser MJ, Smith PD, Ravdin JI, Greenberg HB, Guerrant RL, eds. Infections of the gastrointestinal tract. 2nd ed. Philadelphia: Lippincott Williams \& Wilkins, 2002:45-56.

12. Harper PH, Lee EC, Kettlewell MG, Bennett MK, Jewell DP. Role of the faecal stream in the maintenance of Crohn's colitis. Gut 1985;26:279-284.

13. D'Haens GR, Geboes K, Peeters M, Baert F, Penninckx F, Rutgeerts $P$. Early lesions of recurrent Crohn's disease caused by infusion of intestinal contents in excluded ileum. Gastroenterology 1998;114:262-267.

14. Swidsinski A, Ladhoff A, Pernthaler A, Swidsinski S, LoeningBaucke V, Ortner M, Weber J, Hoffmann U, Schreiber S, Dietel $\mathrm{M}$, Lochs $\mathrm{H}$. Mucosal flora in inflammatory bowel disease. Gastroenterology 2002;122:44-54.

15. Cartun RW, Van Kruiningen HJ, Pedersen CA, Berman MM. An immunocytochemical search for infectious agents in Crohn's disease. Mod Pathol 1993;6:212-219.

16. Ogura $\mathrm{Y}$, Bonen DK, Inohara N, Nicolae DL, Chen F, Ramos R, Britton H, Moran T, Karaliuskas R, Duerr RH, Achkar JP, Brant SR, Bayless TM, Kirschner BS, Hanauer SB, Nunez G, Cho JH. A frameshift mutation in NOD2 associated with susceptibility to Crohn's disease. Nature 2001;411:603-606.

17. Hugot JP, Chamaillard M, Zouali H, Lesage S, Cezard JP, Belaiche J, Almer S. Association of NOD2 leucine-rich repeat variants with susceptibility to Crohn's disease. Nature 2001;411: $599-603$

18. Girardin SE, Boneca IG, Viala J, Chamaillard M, Labigne A, Thomas G, Philpott DJ, Sansonetti PJ. Nod2 is a general sensor of peptidoglycan through muramyl dipeptide (MDP) detection. J Biol Chem 2003;278:8869-8872.

19. Hisamatsu T, Suzuki M, Reinecker HC, Nadeau WJ, McCormick BA, Podolsky DK. CARD15/NOD2 functions as an anti-bacterial factor in human intestinal epithelial cells. Gastroenterology 2003:124:993-1000.

20. Fellermann K, Wehkamp J, Herrlinger KR, Stange EF. Crohn's disease: a defensin deficiency syndrome? Eur J Gastroenterol Hepatol 2003;15:627-634.

21. Duchmann R, Kaiser I, Hermann E, Mayet W, Ewe K, Meyer zum Buschenfelde $\mathrm{KH}$. Tolerance exists towards resident intestinal flora but is broken in active inflammatory bowel disease (IBD). Clin Exp Immunol 1995;102:448-455.

22. Macpherson A, Khoo UY, Forgacs I, Philpott-Howard J, Bjarnason I. Mucosal antibodies in inflammatory bowel disease are directed against intestinal bacteria. Gut 1996;38:365-375.

23. Neut $C$, Bulois $P$, Desreumaux $P$, Membre JM, Lederman E, Gambiez L, Cortot A, Quandalle P, van Kruiningen $\mathrm{H}$, Colombel $J F$. Changes in the bacterial flora of the neoterminal ileum after ileocolonic resection for Crohn's disease. Am J Gastroenterol 2002;97:939-946
24. Rath HC, Herfarth HH, Ikeda JS, Grenther WB, Hamm TEJ, Balish E, Taurog JD, Hammer RE, Wilson KH, Sartor RB. Normal luminal bacteria, especially Bacteroides species, mediate chronic colitis, gastritis, and arthritis in HLA-B27/human beta2 microglobulin transgenic rats. J Clin Invest 1996;98:945-953.

25. Kim SC, Tonkonogy SL, Albright CA, Sartor RB. Regional and host specificity of colitis in mice monoassociated with different nonpathogenic bacteria (abstr). Gastroenterology 2003;124: A485

26. Sellon RK, Tonkonogy S, Schultz M, Dieleman LA, Grenther W, Balish E, Rennick DM, Sartor RB. Resident enteric bacteria are necessary for development of spontaneous colitis and immune system activation in interleukin-10-deficient mice. Infect Immun 1998;66:5224-5231.

27. Castiglione F, Del Vecchio B, Rispo A, Petrelli G, Amalfi G, Cozzolino A, Cuccaro I, Mazzacca G. Orocecal transit time and bacterial overgrowth in patients with Crohn's disease. J Clin Gastroenterol 2000;31:63-66.

28. Castiglione F, Rispo A, Di Girolamo E, Cozzolino A, Manguso F, Grassia R, Mazzacca G. Antibiotic treatment of small bowel bacterial overgrowth in patients with Crohn's disease. Aliment Pharmacol Ther 2003;18:1107-1112.

29. Bernstein LH, Frank MS, Brandt LJ, Boley SJ. Healing of perineal Crohn's disease with metronidazole. Gastroenterology 1980; 79:357-365

30. Colombel JF, Cortot A, Van Kruiningen HJ. Antibiotics in Crohn's disease. Gut 2001;48:647.

31. Sartor RB. Microbial and dietary factors in the pathogenesis of chronic, immune-mediated intestinal inflammation. In: Blumberg RS, Neurath ME, eds. Immune mechanisms in inflammatory bowel diseases. 2004 (in press).

32. Present DH. How to do without steroids in inflammatory bowel disease. Inflamm Bowel Dis 2000;6:48-57.

33. Sartor RB. Antibiotics as therapeutic agents in Crohn's disease. In: Bayless TM, Hanauer S, eds. Current advanced therapy of inflammatory bowel disease. Hamilton, B.C. Decker, Inc., 2000: 359-362.

34. Sutherland L, Singleton J, Sessions J, Hanauer S, Krawitt E, Rankin G, Summers R, Mekhjian H, Greenberger N, Kelly M. Double blind, placebo controlled trial of metronidazole in Crohn's disease. Gut 1991;32:1071-1075.

35. Ursing B, Alm T, Barany F, Bergelin I, Ganrot-Norlin K, Hoevels J, Huitfeldt B, Jarnerot G, Krause U, Krook A, Lindstrom B, Nordle 0 , Rosen A. A comparative study of metronidazole and sulfasalazine for active Crohn's disease: the cooperative Crohn's disease study in Sweden. II. Result. Gastroenterology 1982;83: 550-562.

36. Greenbloom SL, Steinhart AH, Greenberg GR. Combination ciprofloxacin and metronidazole for active Crohn's disease. Can $J$ Gastroenterol 1998;12:53-56.

37. Steinhart AH, Feagan BG, Wong CJ, Vandervoort M, Mikolainis S, Croitoru K, Seidman E, Leddin DJ, Bitton A, Drouin E, Cohen A, Greenberg GR. Combined budesonide and antibiotic therapy for active Crohn's disease: a randomized controlled trial. Gastroenterology 2002;123:33-40.

38. Rutgeerts P, Hiele M, Geboes K, Peeters M, Penninckx F, Aerts $\mathrm{R}$, Kerremans R. Controlled trial of metronidazole treatment for prevention of Crohn's recurrence after ileal resection. Gastroenterology 1995;108:1617-1621.

39. Rutgeerts P, Van Assche G, D'Haens G, Baert F, Noman M, Aerden I, Geboes K, D'Hoore A, Penninckx F. Ornidazol for prophylaxis of postoperative Crohn's disease: final results of a double blind placebo controlled trial (abstr). Gastroenterology 2002;122:A80.

40. Krook A, Lindstrom B, Kjellander J, Jarnerot G, Bodin L. Relation between concentrations of metronidazole and Bacteroides spp 
in faeces of patients with Crohn's disease and healthy individuals. J Clin Pathol 1981;34:645-650.

41. Colombel JF, Lemann M, Cassagnou M, Bouhnik Y, Duclos B, Dupas JL, Notteghem B, Mary JY. A controlled trial comparing ciprofloxacin with mesalamine for the treatment of active Crohn's disease. Groupe d'Etudes Therapeutiques des Affections Inflammatoires Digestives (GETAID). Am J Gastroenterol 1999;94:674-678.

42. Arnold GL, Beaves MR, Pryjdun VO, Mook WJ. Preliminary study of ciprofloxacin in active Crohn's disease. Inflamm Bowel Dis 2002;8:10-15.

43. Prantera C, Zannoni F, Scribano ML, Berto E, Andreoli A, Kohn A, Luzi C. An antibiotic regimen for the treatment of active Crohn's disease: a randomized, controlled clinical trial of metronidazole plus ciprofloxacin. Am J Gastroenterol 1996;91:328-332.

44. Prantera C, Berto E, Scribano ML, Falasco G. Use of antibiotics in the treatment of active Crohn's disease: experience with metronidazole and ciprofloxacin. Ital J Gastroenterol Hepatol 1998;30:602-606.

45. Leiper K, Morris Al, Rhodes JM. Open label trial of oral clarithromycin in active Crohn's disease. Aliment Pharmacol Ther 2000; 14:801-806.

46. Shafran I, Johnson LK, Hamm L, Murdock RHJ. Efficacy and tolerability of rifaximin, a nonabsorbed oral antibiotic, in the treatment of active Crohn's disease: results of an open-label study (abstr). Am J Gastroenterol 2003;98:S250.

47. Borgaonkar MR, Maclntosh DG, Fardy JM. A meta-analysis of antimycobacterial therapy for Crohn's disease. Am J Gastroenterol 2000;95:725-729.

48. Gui GP, Thomas PR, Tizard ML, Lake J, Sanderson JD, HermonTaylor J. Two-year-outcomes analysis of Crohn's disease treated with rifabutin and macrolide antibiotics. J Antimicrob Chemother 1997;39:393-400.

49. Borody TJ, Leis S, Warren EF, Surace R. Treatment of severe Crohn's disease using antimycobacterial triple therapy-approaching a cure? Dig Liver Dis 2002;34:29-38.

50. Shafran I, Kugler L, el-Zaatari FA, Naser SA, Sandoval J. Open clinical trial of rifabutin and clarithromycin therapy in Crohn's disease. Dig Liver Dis 2002;34:22-28.

51. Schwartz DA, Pemberton JH, Sandborn WJ. Diagnosis and treatment of perianal fistulas in Crohn disease. Ann Intern Med 2001;135:906-918.

52. Brandt LJ, Bernstein LH, Boley SJ, Frank MS. Metronidazole therapy for perineal Crohn's disease: a follow-up study. Gastroenterology 1982;83:383-387.

53. Solomon MR, McLeod R. Combination ciprofloxacin and metronidazole in severe perianal Crohn's disease. Can J Gastroenterol 1993; 7:571-573.

54. Gugler R, Jensen JC, Schulte H, Vogel R. The course of Crohn disease and side effect profile with long-term treatment using metronidazole. Z Gastroenterol 1989;27:676-682.

55. Burke DA, Axon AT, Clayden SA, Dixon MF, Johnston D, Lacey RW. The efficacy of tobramycin in the treatment of ulcerative colitis. Aliment Pharmacol Ther 1990;4:123-129.

56. Burke DA, Clayden SA, Dixon MF, Axon AT, Johnston D, Lacey RW. A follow up study of adjunctive oral tobramycin therapy in acute ulcerative colitis (abstr). Gastroenterology 1988;94:A55.

57. Danzi JT. Trimethoprim-sulphamethoxazole therapy of inflammatory bowel disease (abstr). Gastroenterology 1989;96:A110.

58. Turunen U, Farkkila MA, Valtonen V. Long-term treatment of ulcerative colitis with ciprofloxacin. Gastroenterology 1999;117: 282-283.

59. Mantzaris GJ, Archavlis E, Christoforidis P, Kourtessas D, Amberiadis $\mathrm{P}$, Florakis N, Petraki K, Spiliadi C, Triantafyllou G. A prospective randomized controlled trial of oral ciprofloxacin in acute ulcerative colitis. Am J Gastroenterol 1997;92:454-456.

60. Mantzaris GJ, Petraki K, Archavlis E, Amberiadis P, Kourtessas
D, Christidou A, Triantafyllou G. A prospective randomized controlled trial of intravenous ciprofloxacin as an adjunct to corticosteroids in acute, severe ulcerative colitis. Scand J Gastroenterol 2001;36:971-974.

61. Lukas M, Konecny M, Zboril V. Rifaximin in patients with mild to moderate activity of ulcerative colitis: an open label study (abstr). Am J Gastroenterol 2003;98:A434.

62. Peppercorn MA. Are antibiotics useful in the management of nontoxic severe ulcerative colitis? J Clin Gastroenterol 1993; 17:14-17.

63. Brigidi P, Swennen E, Rizzello F, Bozzolasco M, Matteuzzi D. Effects of rifaximin administration on the intestinal microbiota in patients with ulcerative colitis. J Chemother 2002;14:290295.

64. Madden MV, McIntyre AS, Nicholls RJ. Double-blind crossover trial of metronidazole versus placebo in chronic unremitting pouchitis. Dig Dis Sci 1994;39:1193-1196.

65. Gionchetti P, Amadini C, Rizzello F, Venturi A, Poggioli G, Campieri M. Diagnosis and treatment of pouchitis. Best Pract Res Clin Gastroenterol 2003;17:75-87.

66. Shen B, Achkar JP, Lashner BA, Ormsby AH, Remzi FH, Brzezinski A, Bevins CL, Bambrick ML, Seidner DL, Fazio VW. A randomized clinical trial of ciprofloxacin and metronidazole to treat acute pouchitis. Inflamm Bowel Dis 2001;7:301-305.

67. Gionchetti P, Rizzello F, Venturi A, Ugolini F, Rossi M, Brigidi P, Johansson R, Ferrieri A, Poggioli G, Campieri M. Antibiotic combination therapy in patients with chronic, treatment-resistant pouchitis. Aliment Pharmacol Ther 1999;13:713-718.

68. Rath HC, Schultz M, Freitag R, Dieleman LA, Li F, Linde HJ, Scholmerich J, Sartor RB. Different subsets of enteric bacteria induce and perpetuate experimental colitis in rats and mice. Infect Immun 2001;69:2277-2285.

69. Madsen KL, Doyle JS, Tavernini MM, Jewell LD, Rennie RP, Fedorak RN. Antibiotic therapy attenuates colitis in interleukin 10 gene-deficient mice. Gastroenterology 2000;118:10941055.

70. Hoentjen F, Harmsen HJ, Braat H, Torrice CD, Mann BA, Sartor RB, Dieleman LA. Antibiotics with a selective aerobic or anaerobic spectrum have different therapeutic activities in various regions of the colon in interleukin-10 gene deficient mice. Gut 2003;52:1721-1727.

71. Fiorucci S, Distrutti E, Mencarelli A, Barbanti M, Palazzini E, Morelli A. Inhibition of intestinal bacterial translocation with rifaximin modulates lamina propria monocytic cells reactivity and protects against inflammation in a rodent model of colitis. Digestion 2002;66:246-256.

72. Bamias G, Marini M, Moskaluk CA, Odashima M, Ross WG, Rivera-Nieves J, Cominelli F. Down-regulation of intestinal lymphocyte activation and Th1 cytokine production by antibiotic therapy in a murine model of Crohn's disease. J Immunol 2002; 169:5308-5314.

73. Yamada T, Deitch E, Specian RD, Perry MA, Sartor RB, Grisham MB. Mechanisms of acute and chronic intestinal inflammation induced by indomethacin. Inflammation 1993;17:641-662.

74. Onderdonk AB, Hermos JA, Dzink JL, Bartlett JG. Protective effect of metronidazole in experimental ulcerative colitis. Gastroenterology 1978;74:521-526.

75. Videla S, Vilaseca J, Guarner F, Salas A, Treserra F, Crespo E, Antolin M, Malagelada JR. Role of intestinal microflora in chronic inflammation and ulceration of the rat colon. Gut 1994;35: 1090-1097.

76. Dieleman LA, Goerres M, Arends A, Sprengers D, Torrice C, Hoentjen F, Grenther WB, Sartor RB. Lactobacillus GG prevents recurrence of colitis in HLA-B27 transgenic rats after antibiotic treatment. Gut 2003;52:370-376.

77. Gionchetti $P$, Rizzello F, Venturi A, Brigidi P, Matteuzzi D, Bazzocchi G, Poggioli G, Miglioli M, Campieri M. Oral bacterio- 
therapy as maintenance treatment in patients with chronic pouchitis: a double-blind, placebo-controlled trial. Gastroenterology 2000;119:305-309.

78. Schultz M, Rath HC. The possible role of probiotic therapy in inflammatory bowel disease. In: Tannock GW, ed. Probiotics and prebiotics: where are we going? Wymondham, UK: Caister Academic Press, 2002:175-237.

79. Shanahan F. Probiotics and inflammatory bowel disease: from fads and fantasy to facts and future. Br J Nutr 2002;88(suppl 1):S5-S9.

80. Shanahan F. Probiotics: a perspective on problems and pitfalls. Scand J Gastroenterol Suppl 2003;237:34-36.

81. Hart AL, Kamm MA. Use of probiotics in the treatment of inflammatory bowel disease. J Clin Gastroenterol 2003;36:111-119.

82. Famularo G, Mosca L, Minisola G, Trinchieri V, De Simone C. Probiotic lactobacilli: a new perspective for the treatment of inflammatory bowel disease. Curr Pharm Des 2003;9:19731980.

83. Mimura T, Rizzello F, Schreiber S, Talbot IC, Nicholls RJ, Gionchetti P, Campieri M, Kamm MA. Once daily high dose probiotic therapy maintains remission and improved quality of life in patients with recurrent or refractory pouchitis: a randomised, placebo-controlled, double-blind trial (abstr). Gastroenterology 2002;122:A81.

84. Gionchetti P, Rizzello F, Helwig U, Venturi A, Lammers KM, Brigidi P, Vitali B, Poggioli G, Miglioli M, Campieri M. Prophylaxis of pouchitis onset with probiotic therapy: a double-blind placebo controlled trial. Gastroenterology 2003:124:1202-1209.

85. Kruis W, Schutz E, Fric P, Fixa B, Judmaier G, Stolte M. Doubleblind comparison of an oral Escherichia coli preparation and mesalazine in maintaining remission of ulcerative colitis. Aliment Pharmacol Ther 1997;11:853-858.

86. Rembacken BJ, Snelling AM, Hawkey PM, Chalmers DM, Axon AT. Non-pathogenic Escherichia coli versus mesalazine for the treatment of ulcerative colitis: a randomised trial. Lancet 1999; 354:635-639.

87. Kruis W, Kalk EK, Fric $P$, Stolte M. Maintenance of remission in ulcerative colitis is equally effective with Escherichia coli Nissle 1917 and with standard mesalamine (abstr). Gastroenterology 2001;120:A127.

88. Ishikawa H, Akedo I, Umesaki Y, Tanaka R, Imaoka A, Otani T. Randomized controlled trial of the effect of bifidobacteria-fermented milk on ulcerative colitis. J Am Coll Nutr 2003;22:5663.

89. Venturi A, Gionchetti P, Rizzello F, Johansson R, Zucconi E, Brigidi P, Matteuzzi D, Campieri M. Impact on the composition of the faecal flora by a new probiotic preparation: preliminary data on maintenance treatment of patients with ulcerative colitis. Aliment Pharmacol Ther 1999;13:1103-1108.

90. Fedorak RN, Gionchetti P, Campieri M, De Simone C, Madsen K, Isaacs KL, Sartor RB. VSL3 probiotic mixture induces remission in patients with active ulcerative colitis (abstr). Gastroenterology 2003;124:A377.

91. Guslandi M, Giollo P, Testoni PA. A pilot trial of Saccharomyces boulardii in ulcerative colitis. Eur J Gastroenterol Hepatol 2003; 15:697-698.

92. Borody TJ, Warren EF, Leis S, Surace R, Ashman O. Treatment of ulcerative colitis using fecal bacteriotherapy. J Clin Gastroenterol 2003;37:42-47.

93. Malchow HA. Crohn's disease and Escherichia coli. A new approach in therapy to maintain remission of colonic Crohn's disease? J Clin Gastroenterol 1997;25:653-658.

94. Prantera C, Scribano ML, Falasco G, Andreoli A, Luzi C. Ineffectiveness of probiotics in preventing recurrence after curative resection for Crohn's disease: a randomised controlled trial with Lactobacillus GG. Gut 2002;51:405-409.
95. Guandalini S. Use of Lactobacillus-GG in paediatric Crohn's disease. Dig Liver Dis 2002;34(suppl 2):S63-S65.

96. Madsen KL, Doyle JS, Jewell LD, Tavernini MM, Fedorak RN. Lactobacillus species prevents colitis in interleukin 10 genedeficient mice. Gastroenterology 1999;116:1107-1114.

97. Madsen K, Cornish A, Soper P, McKaigney C, Jijon H, Yachimec C, Doyle J, Jewell L, De Simone C. Probiotic bacteria enhance murine and human intestinal epithelial barrier function. Gastroenterology 2001;121:580-591.

98. Schultz M, Veltkamp C, Dieleman LA, Grenther WB, Wyrick PB, Tonkonogy SL, Sartor RB. Lactobacillus plantarum $299 \mathrm{~V}$ in the treatment and prevention of spontaneous colitis in interleukin-10 deficient mice. Inflamm Bowel Dis 2002;8:71-80.

99. McCarthy J, O'Mahony L, O'Callaghan L, Sheil B, Vaughan EE, Fitzsimons N, Fitzgibbon J, O'Sullivan GC, Kiely B, Collins JK, Shanahan F. Double blind, placebo controlled trial of two probiotic strains in interleukin 10 knockout mice and mechanistic link with cytokine balance. Gut 2003;52:975-980.

100. Steidler L, Hans W, Schotte L, Neirynck S, Obermeier F, Falk W, Fiers W, Remaut E. Treatment of murine colitis by Lactococcus lactis secreting interleukin-10. Science 2000;289:1352-1355.

101. Shiba T, Aiba Y, Ishikawa H, Ushiyama A, Takagi A, Mine T, Koga $Y$. The suppressive effect of bifidobacteria on Bacteroides vulgatus, a putative pathogenic microbe in inflammatory bowel disease. Microbiol Immunol 2003;47:371-378.

102. Rath HC, Wilson KH, Sartor RB. Differential induction of colitis and gastritis in HLA-B27 transgenic rats selectively colonized with Bacteroides vulgatus and Escherichia coli. Infect Immun 1999;67:2969-2974.

103. Boudeau J, Glasser AL, Julien S, Colombel JF, DarfeuilleMichaud A. Inhibitory effect of probiotic Escherichia coli strain Nissle 1917 on adhesion to and invasion of intestinal epithelial cells by adherent-invasive $E$. coli strains isolated from patients with Crohn's disease. Aliment Pharmacol Ther 2003;18:45-56.

104. Mack DR, Michail S, Wei S, McDougall L, Hollingsworth MA. Probiotics inhibit enteropathogenic $E$. coli adherence in vitro by inducing intestinal mucin gene expression. Am J Physiol 1999; 276:G941-G950.

105. Trivedi K, Barrett KE, Resta-Lenert SC. Probiotic inhibition of the entry of enteroinvasive $E$. coli into human intestinal epithelial cells involves both Rho-dependent and independent pathways (abstr). Gastroenterology 2003;124:A106.

106. Mattar AF, Teitelbaum DH, Drongowski RA, Yongyi F, Harmon CM, Coran AG. Probiotics up-regulate MUC-2 mucin gene expression in a Caco-2 cell-culture model. Pediatr Surg Int 2002; 18:586-590.

107. Pavan S, Desreumaux P, Mercenier A. Use of mouse models to evaluate the persistence, safety, and immune modulation capacities of lactic acid bacteria. Clin Diagn Lab Immunol 2003; 10:696-701.

108. Mattar AF, Drongowski RA, Coran AG, Harmon CM. Effect of probiotics on enterocyte bacterial translocation in vitro. Pediatr Surg Int 2001;17:265-268.

109. Ulisse S, Gionchetti P, D'Alo S, Russo FP, Pesce I, Ricci G, Rizzello F, Helwig U, Cifone MG, Campieri M, De Simone C. Expression of cytokines, inducible nitric oxide synthase, and matrix metalloproteinases in pouchitis: effects of probiotic treatment. Am J Gastroenterol 2001;96:2691-2699.

110. Pathmakanthan S, Li CK, Cowie J, Hawkey CJ. Lactobacillus plantarum 299: beneficial in vitro immunomodulation in cells extracted from inflamed human colon. J Gastroenterol Hepatol 2004;19:166-173.

111. Borruel N, Carol M, Casellas F, Antolin M, de Lara F, Espin E, Naval J, Guarner F, Malagelada JR. Increased mucosal tumour necrosis factor alpha production in Crohn's disease can be downregulated ex vivo by probiotic bacteria. Gut 2002;51:659 664. 
112. Cender CJ, Haller D, Walters C, Sartor RB. VSL \#3 alters cytokine production of unfractionated splenocytes upon stimulation with cecal bacterial lysate: immunomodulation by this probiotic combination (abstr). Gastroenterology 2002;122:A145.

113. Jijon HB, Backer J, Diaz H, Yeung H, Thiel D, McKaigney C, De Simone C, Madsen K. DNA from probiotic bacteria modulates murine and human epithelial and immune function. Gastroenterology 2004;126 (in press).

114. Yan F, Polk DB. Probiotic bacterium prevents cytokine-induced apoptosis in intestinal epithelial cells. J Biol Chem 2002;277: 50959-50965.

115. Rachmilewitz D, Katakara K, Karmeli F, Hayashi T, Reinus C, Akira S, Lee J, Takabayashi K, Takeda K, Raz E. Toll-like receptor 9 signaling mediates the anti-inflammatory effects of probiotics in murine experimental colitis. Gastroenterology 2004; 126:520-528.

116. Cummings JH. Dietary carbohydrates and the colonic microflora. Curr Opin Clin Nutr Metab Care 1998;1:409-414.

117. Bird AR, Brown IL, Topping DL. Starches, resistant starches, the gut microflora and human health. Curr Issues Intest Microbiol 2000;1:25-37.

118. Jacobasch G, Schmiedl D, Kruschewski M, Schmehl K. Dietary resistant starch and chronic inflammatory bowel diseases. Int J Colorectal Dis 1999;14:201-211.

119. Kanauchi O, Mitsuyama K, Homma T, Takahama K, Fujiyama $Y$, Andoh A, Araki Y, Suga T, Hibi T, Naganuma M, Asakura $H$, Nakano H, Shimoyama T, Hida N, Haruma K, Koga H, Sata M, Tomiyasu N, Toyonaga A, Fukuda M, Kojima A, Bamba T. Treatment of ulcerative colitis patients by long-term administration of germinated barley foodstuff: multi-center open trial. Int J Mol Med 2003;12:701-704.

120. Bamba T, Kanauchi O, Andoh A, Fujiyama Y. A new prebiotic from germinated barley for nutraceutical treatment of ulcerative colitis. J Gastroenterol Hepatol 2002;17:818-824.

121. Mitsuyama K, Toyonaga A, Sata M. Intestinal microflora as a therapeutic target in inflammatory bowel disease. J Gastroenterol 2002;37(Suppl 14):73-77.

122. Kanauchi O, Suga T, Tochihara M, Hibi T, Naganuma M, Homma T, Asakura H, Nakano H, Takahama K, Fujiyama Y, Andoh A, Shimoyama T, Hida N, Haruma K, Koga H, Mitsuyama K, Sata M, Fukuda M, Kojima A, Bamba T. Treatment of ulcerative colitis by feeding with germinated barley foodstuff: first report of a multicenter open control trial. J Gastroenterol 2002;37:67-72.

123. Hallert C, Kaldma M, Petersson BG. Ispaghula husk may relieve gastrointestinal symptoms in ulcerative colitis in remission. Scand J Gastroenterol 1991;26:747-750.

124. Videla S, Vilaseca J, Antolin M, Garcia-Lafuente A, Guarner F, Crespo E, Casalots J, Salas A, Malagelada JR. Dietary inulin improves distal colitis induced by dextran sodium sulfate in the rat. Am J Gastroenterol 2001;96:1486-1493.

125. Araki Y, Andoh A, Koyama S, Fujiyama Y, Kanauchi O, Bamba T. Effects of germinated barley foodstuff on microflora and short chain fatty acid production in dextran sulfate sodium-induced colitis in rats. Biosci Biotechnol Biochem 2000;64:17941800.
126. Fukuda M, Kanauchi O, Araki Y, Andoh A, Mitsuyama K, Takag K, Toyonaga A, Sata M, Fujiyama Y, Fukuoka M, Matsumoto Y, Bamba T. Prebiotic treatment of experimental colitis with germinated barley foodstuff: a comparison with probiotic or antibiotic treatment. Int J Molec Med 2002;9:65-70.

127. Kanauchi O, Serizawa I, Araki Y, Suzuki A, Andoh A, Fujiyama Y, Mitsuyama K, Takaki K, Toyonaga A, Sata M, Bamba T. Germinated barley foodstuff, a prebiotic product, ameliorates inflammation of colitis through modulation of the enteric environment. J Gastroenterol 2003;38:134-141.

128. Cherbut C, Michel C, Lecannu G. The prebiotic characteristics of fructooligosaccharides are necessary for reduction of TNBSinduced colitis in rats. J Nutr 2003;133:21-27.

129. Moreau NM, Martin L, Toquet CS, Laboisse CL, Nguyen PG, Siliart BS, Dumon HJ, Champ MM. Restoration of the integrity of rat caeco-colonic mucosa by resistant starch, but not by fructooligosaccharides, in dextran sulfate sodium-induced experimental colitis. Br J Nutr 2003;90:75-85.

130. Holma R, Juvonen $\mathrm{P}$, Asmawi MZ, Vapaatalo H, Korpela R. Galacto-oligosaccharides stimulate the growth of bifidobacteria but fail to attenuate inflammation in experimental colitis in rats. Scand J Gastroenterol 2002;37:1042-1047.

131. Hoentjen F, Zhang X, Tannock GW, Dieleman LA. The prebiotic combination inulin and oligofructose prevents colitis in HLA-B27 transgenic rats (abstr). Gastroenterology 2004;126 (in press).

132. Kleessen B, Hartmann L, Blaut M. Oligofructose and long-chain inulin: influence on the gut microbial ecology of rats associated with a human faecal flora. Br J Nutr 2001;86:291-300.

133. Hopkins MJ, Macfarlane GT. Nondigestible oligosaccharides enhance bacterial colonization resistance against Clostridium difficile in vitro. Appl Environ Microbiol 2003;69:1920-1927.

134. Casellas F, Borruel N, Papo M, Guarner F, Antolin M, Videla S, Malagelada JR. Antiinflammatory effects of enterically coated amoxicillin-clavulanic acid in active ulcerative colitis. Inflamm Bowel Dis 1998;4:1-5.

135. Plein K, Hotz J. Therapeutic effects of Saccharomyces boulardii on mild residual symptoms in a stable phase of Crohn's disease with special respect to chronic diarrhea-a pilot study. Z Gastroenterol 1993;31:129-134.

136. Guslandi M, Mezzi G, Sorghi M, Testoni PA. Saccharomyces boulardii in maintenance treatment of Crohn's disease. Dig Dis Sci 2000;45:1462-1464.

Received February 4, 2004. Accepted March 4, 2004.

Address requests for reprints to: R. Balfour Sartor, M.D., University of North Carolina Department of Medicine/Division of Gastroenterology and Hepatology, Room 7309 Biomolecular Building, MBRB, CB \#7032, Chapel Hill, North Carolina 27599-7032. e-mail: rbs@med. unc.edu; fax: (919) 843-6899.

Dr. Sartor has received research support and is a consultant for VSL 3 Pharmaceuticals, and has received honoraria for speaking at symposia and creating a videotape and monograph sponsored by Salix Pharmaceuticals. 